Reprod. Nutr. Dévelop., 1983, 23 (4), 775-781.

\title{
Hormonal levels after ovarian X-irradiation of ewes
}

\author{
M.-A. DRIANCOURT, M. R. BLANC, J.-C. MARIANA
}

Station de Physiologie de la Reproduction, I.N.R.A., Nouzilly, 37380 Monnaie, France

Summary. This paper reports the effects of $\mathrm{X}$-irradiation on ovulation rate, cyclicity and progesterone and FSH levels in lle-de-France ewes (4 control and 16 irradiated) after they were treated during the breeding season. The doses used ( 800 and $2400 \mathrm{R}$ ) destroyed $50 \%$ of all size classes of the follicular population.

Ovulation occurred in $87 \%$ of the treated ewes (ovulation rate $=1$ ) when they were irradiated $24 \mathrm{~h}$ after luteolysis; $78 \%$ of the corpora lutea resulting from these ovulations were normal as to length and progesterone production. FSH in treated ewes started to increase $20 \mathrm{~h}$ after treatment and remained higher than in the controls until ovulation time. Later, while these levels were similar between groups on the day of ovulation, high ovulatory levels persisted in irradiated ewes. In the next cycles, the length of the follicular phases, ovulation rate and progesterone and FSH levels were similar between groups.

\section{Introduction.}

The ovarian follicular population in sheep is reduced by half either by hemicastration (Dufour, Cahill and Mauléon, 1979) or by low and medium doses (800 and $2400 \mathrm{R}$ ) of $\mathrm{X}$-rays (Driancourt and Mariana, 1982). When comparing the long-term effects of such treatments, no follicular compensation similar to that occurring in hemicastrated ewes (Dufour, Cahill and Mauléon, 1979) is evident in irradiated ewes since :

1) the mean diameter of each of the four largest healthy follicles in long-term irradiated animals is smaller than in control ewes ;

2) the number of follicles larger than $1500 \mu \mathrm{m}$ in diameter is not doubled in long-term animals compared to short-term irradiated ones, and

3) there are no clear-cut modifications in the extent of atresia in long-term animals.

The only follicular compensation after irradiation is limited to follicles between 200 and $300 \mu \mathrm{m}$ in diameter (Driancourt and Mariana, 1981). The present work was undertaken to determine if cyclicity, ovulation rate and FSH levels were altered after an X-ray-induced reduction in the follicular populations in the cycle immediately after $X$-irradiation and-in later cycles. 


\section{Material and methods.}

Experimental design. - Twenty lle-de-France ewes were used. During the breeding season, oestrus was synchronized using progestagen-impregnated sponges $(40 \mathrm{mg}$ of Cronolone, SC 9880, Searle France). On day 13 after synchronized ovulation, all the animals received an intramuscular injection of $100 \mu \mathrm{g}$ of $\mathrm{ICl} 80996$ (a prostaglandin analogue) to induce regression of the corpus luteum. Twenty-four hours later, they were either laparotomized ( $n=4$ ) or laparotomized and irradiated ( $n=16$ ). At laparotomy, the main features of the ovaries (number, side of medium and large-sized follicles, side of regressing $C L$ ) were noted. Irradiation was performed as follows. Both ovaries were irradiated together using an X-ray machine operating at $280 \mathrm{kv}$ and $20 \mathrm{~mA}$ and delivering $70 \mathrm{R} / \mathrm{min}$. We used two X-ray levels : 800 and $2400 \mathrm{R}$. However, due to close similarities in the follicular populations of the animals irradiated at either level (Driancourt and Mariana, 1982), this factor will not be considered in the present study.

Four days after treatment, each animal underwent endoscopy to determine whether ovulation had occurred and on which side it had taken place. Treatment effect was then determined at two time intervals; half of the animals were castrated 10 days after irradiation (short-term animals), while the remainder (long-term animals) were castrated 2 cycles and 10 days (42 days) after X-irradiation.

Blood sampling and hormone assays. - A blood sample was collected once daily from 2 days before prostaglandin injection until the day of ovariectomy. However, FSH is very sensitive to ovarian feedback, showing a quick and transient increase in hemicastrated ewes (Findlay and Cumming, 1977) and a quick increase in castrated rams (Blanc et al., 1981) ; therefore, we applied an intensive blood sampling schedule (collection every $2 \mathrm{~h}$ ) in 6 ewes ( 2 control and 4 irradiated) from surgery time to $30 \mathrm{~h}$ later.

After each sampling, the blood was centrifuged immediately, and the plasma stored at $-15^{\circ} \mathrm{C}$ until assayed. Ovarian cyclicity and the quality of the corpora lutea were assessed by progesterone assay as described by Yenikoye et al. (1981). Assay sensitivity was around $0.03 \mathrm{ng} / \mathrm{ml}$; the intra-assay coefficient of variation was $40 \%$ for plasma containing $0.03 \mathrm{ng} / \mathrm{ml}$ and $8.5 \%$ for plasma containing $16 \mathrm{ng} / \mathrm{ml}$. To eliminate inter-assay variations, all samples of progesterone as well as of FSH were assayed in a single assay. FSH levels were measured according to Blanc and Poirier (1979). Assay sensitivity was $2.4 \mathrm{ng}$ of $\mathrm{FSH} \mathrm{S}_{3} / \mathrm{ml}$ of plasma and within assay variation was $5 \%$.

Analysis of data. - The follicular phase was defined as the interval between the decrease of progesterone levels under $0.5 \mathrm{ng} / \mathrm{ml}$, i.e. luteolysis, and the next increase over $0.5 \mathrm{ng} / \mathrm{ml}$ subsequent to ovulation.

Ovulation was said to occur $48 \mathrm{~h}$ before the progesterone level reached $0.5 \mathrm{ng} / \mathrm{ml}$ and was coincident with the time of the second FSH peak (Pant et al., 1977). The magnitude of this second FSH peak was defined as the mean value of FSH levels at days 1, 2 and 3 after ovulation. 
Length and level of progesterone secretion have been considered to define the normalcy of the CL. A corpus luteum was said to be normal if it secreted at least $0.5 \mathrm{ng} / \mathrm{ml}$ for at least 8 days (Cognié, personal communication).

All hormone levels were expressed as the mean \pm standard deviation. Owing to the inequality of variances between groups in most cases, we used nonparametric testing (Siegel, 1956), i.e. mainly the Wilcoxon matched-pairs signedranks test to compare levels within animals and the Mann-Whitney U-test to test differences between groups.

\section{Results.}

Cyclicity and ovulation rate in short-term animals. - After treatment, ovulation occurred in $4 / 4$ control (ovulation rate $=1$ ) and $14 / 16$ irradiated (ovulation rate $=1$ ) animals. In the 14 ewes ovulating after X-irradiation, 11 corpora lutea were normal and 3 were abnormal, surviving for only 5 to 7 days. But the percentage of normal ovulation did not differ significantly between control and irradiated animals.

Nevertheless, the levels of progesterone secreted by the normal corpora lutea tended to be lower in X-irradiated ewes than in controls (X-irradiated : $2.17 \pm 0.32 \mathrm{ng} / \mathrm{ml}$, controls : $2.56 \pm 0.28 ; U=9 ; 0.05<p<0.1$ ) during the plateau of progesterone release by the CL (days 6 to 10 after ovulation).

Similarly, the length of the follicular phase after treatment tended to be longer in irradiated ewes (irradiated: $7.06 \pm 3.75$, control : $5.5 \pm 1$ day ; $\mathrm{U}=21 \mathrm{NS}$ ) than in controls because three animals had long intervals between treatment and ovulation $(9,10$ and 18 days). However, except for these 3 animals, ovulation took place in the rest of the ewes (4 out of 4 control and 13 out of 13 irradiated ewes) on the ovary bearing the largest follicle at the time of laparotomy, suggesting that terminal follicular growth and ovulation were not impaired by irradiation.

FSH levels during the cycle after irradiation. - Since the intervals between surgery and ovulation were variable, the data on FSH were synchronized to two times : the time of surgery (data obtained from repeated blood sampling) and the time of ovulation (data obtained from daily samples).

In the first $18 \mathrm{~h}$ after treatment, changes in $\mathrm{FSH}$ levels in irradiated ewes were not different from those occurring in control animals. However, after that (20-24 $\mathrm{h}$ and 26-30 $\mathrm{h}$ after irradiation), there was clearly a significant increase in irradiated animals ; using 100 as an index of preoperative levels, the values were 114 vs $150(U=13 ; p<0.05)$ and 126 vs $169(U=18$ NS) for control and irradiated ewes, respectively. This difference between groups was sustained, thus inducing higher, although non-significant, levels of FSH on the 4 days during which the FSH decreased before ovulation (fig. 1). The pattern of FSH levels plotted against the day of ovulation is presented on figure 1. In most cases, the first $\mathrm{FSH}$ peak was not clear owing to the blood sampling schedule used. However, we detected no difference in FSH levels on the day of the second FSH peak (irradiated : $12.4 \pm 4.9$ vs control : $11.5 \pm 7.2 \mathrm{ng} / \mathrm{ml} ; \mathrm{U}=25 \mathrm{NS}$ ). But these levels remained elevated the day after ovulation (irradiated : $14.2 \pm 4.8$ vs 


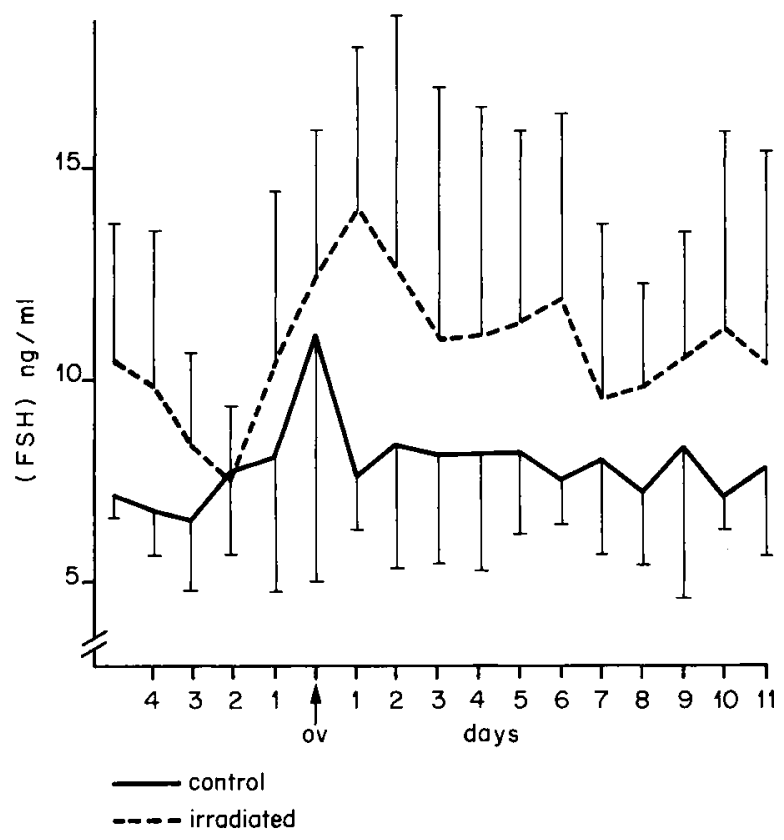

FIG. 1. - FSH levels on the days preceding and following ovulation in control and irradiated ewes in the cycle immediately following ovulation (mean \pm SD).

control : $7.7 \pm 1.2 \mathrm{ng} / \mathrm{ml} ; \mathrm{U}=8.5 ; \mathrm{p}<0.02$ ) and on the following days ; the magnitude of the second FSH peak tended to be higher in irradiated than in control ewes $(12.6 \pm 5.4 \mathrm{vs} 8 \pm 4 \mathrm{ng} / \mathrm{ml} ; U=13 \mathrm{NS})$, and on days 6 and 8 after ovulation irradiated ewes had more FSH than control ones (day 6 : $11.8 \pm 5.4$ vs $7.5 \pm 1.4 \mathrm{ng} / \mathrm{ml} ; U=9 ; p=0.02 ;$ day $8: 9.7 \pm 2.8$ vs $7.2 \pm 2.3 \mathrm{ng} / \mathrm{ml} ; U=9.5 ; \mathrm{p}<0.05$ ) (fig. 1 ).

It should be noted that none of the follicular parameters studied at postirradiation day 10 (total number of healthy antral follicles, number of healthy follicles larger than $0.8 \mathrm{~mm}$ or than $1.3 \mathrm{~mm}$ in diameter, numbers of healthy plus early atretic follicles of these size classes) were correlated with the fluctuations of FSH seen in short-term animals (maximal level on day of ovulation or one day later, magnitude of the second FSH peak). The data that correlated best were the number of follicles with an antrum and the FSH levels on the day after ovulation $(\mathrm{r}=0.67 ; \mathrm{p}=0.1)$.

Cyclicity, ovulation rate and FSH levels in later cycles. - Cyclicity and ovulation rate were very close for long-term ewes and controls. The length of the follicular phases was the same (irradiated : $5.7 \pm 1.82 \mathrm{vs}$ control : $5.5 \pm 1$ day) as were the ovulation rate (irradiated: $1.28 \pm 0.3 \mathrm{vs}$ control : $1 \pm 0$ ) and the progesterone levels on days $6-10$ after ovulation (irradiated; $2.39 \pm 0.54$ vs $2.56 \pm 0.28 \mathrm{ng} / \mathrm{ml}$ for control ; $U=16 \mathrm{NS}$ ). Furthermore, FSH levels were no longer affected by treatment. The magnitude of the second FSH peak did not 
differ between groups (irradiated: $7.9 \pm 1.2$ vs control : $8 \pm 3.1 \mathrm{ng} / \mathrm{ml}$; $\mathrm{U}=12 \mathrm{NS}$ ).

\section{Discussion.}

The results of the present study confirm and extend earlier observations, i.e. that :

1) reducing the follicular numbers by $50 \%$ does not seem to alter the ovulation rate (Land, 1973 ; Findlay and Cumming, 1977), and

2) the decrease in follicular numbers causing alterations in ovarian feedback induces transient modifications of the FSH levels (sheep : Findlay and Cumming, 1977 ; rat : Butcher, 1977 ; hamster : Bast and Greenwald, 1977). In the breed we used, the ovulation rate was not affected by the $50 \%$ reduction in follicular numbers (Driancourt and Mariana, 1982) in either the cycle immediately following the X-rays or in later ones; this rate was still 1 or 2 and had a mean value close to that of lle-de-France ewes (1.4: Thimonier and Mauléon, 1969). Mandl (1963) obtained similar results in rats, showing that irradiation at proestrus did not result in a reduction in the percentage of animals ovulating or in the number of ova shed in later cycles, even with doses as high as $1260 \mathrm{R}$ which very severely depleted the number of follicles available for ovulation (Mandl, 1959). This fairly constant ovulation rate after such a decrease in the follicular population supports the hypothesis postulated for animals with a naturally low level of folliculogenesis lequine : Driancourt et al., 1982; Merino sheep: Cahill, personal communication), i.e. that the minimal population to get one ovulation is low. However, data obtained in monkeys (Hobson and Baker, 1979) contrast with our results since, after irradiation with $4000 \mathrm{R}$, some of them became amenorrhoeic. Possibly the reduction induced by this dose was so high some time after treatment (Baker, 1966) that the population of ovarian follicles in part of the animals remained below the minimal level for maintaining cyclic ovarian activity.

While ovulation of the irradiated large follicle was the rule, a reduced percentage of ewes showed normal CL thereafter ; and despite the fact that these CL were normal according to our criterium, their secretory activity was usually impaired. Similar conclusions were obtained by Regaud and Lacassagne (1913) who showed that irradiation of rabbit ovaries after copulation did not inhibit the formation of corpora lutea but induced their regression as early as $\mathbf{8}$ days after they were formed. Furthermore, Lacassagne (1937) demonstrated a decrease of CL secretory capacity together with a shorter life, suggesting that, while irradiated granulosa cells retain the ability to luteinize, their secretory activity is impaired.

Another purpose of the present study was to determine the alterations in FSH levels caused by an X-ray-induced reduction in follicular numbers. The acute FSH response to irradiation is a surge as soon as $20 \mathrm{~h}$ after treatment. Although the time course of this surge has not been exactly defined, its pattern is close to that described after hemicastration (Findlay and Cumming, 1977) or cautery of all the visible follicles (Cahill and Findlay, personal communication). As FSH levels are known to be controlled by both oestrogens and inhibin (Goodman, Pickover and Karsch, 1981), a reduced secretion of both oestrogen and inhibin by the 
large follicle(s) could be involved in the irradiation-induced surge. Examination of the $\mathrm{FSH}$ pattern during the immediate post-operative cycle raises an interesting question : while it has been clearly demonstrated that the ovulatory FSH peak in intact rats (Hirschfield and Midgley, 1978a, b) triggers the recruitment of follicles due to ovulate at the next cycle and it has been hypothesized in hemicastrated rats (Butcher, 1977) and hamsters (Bast and Greenwald, 1977) that a prolonged FSH peak gives rise to compensatory ovarian hypertrophy, what is the role of the extended second $\mathrm{FSH}$ peak in irradiated ewes? It does not seem to trigger any follicular development since there is no close correlation between any of the follicular parameters studied and the pattern of this second peak. The discrepancy between these results and the claims of a previous study (Cahill et al., 1981) is likely to be due to the fact that the conclusions of the latter were based on two breeds with different follicular populations and FSH levels. Further studies are needed to determine if this second FSH peak consists of bioactive material and to elucidate its control.

Finally, the reasons why the long-term irradiated ovaries did not show a follicular compensation similar to that in hemicastrated ewes (Dufour, Cahill and Mauléon, 1979) are unclear. The irradiated, unsterilized ovary is able to develop follicular compensation after its contralateral ovary is removed (Humphreys and Zuckerman, 1954 ; Mandl, 1963). Further work on hormonal profiles in long-term hemicastrated ewes, comparing them to profiles in irradiated ewes, may permit us to define the mechanisms involved in this lack of compensation (hormonal and/or neural).

Reçu en décembre 1982. Accepté en mars 1983.

Résumé. Effet sur les niveaux hormonaux et le taux d'ovulation de l'irradiation des ovaires chez la brebis.

Les effets de l'irradiation aux rayons $X$, qui détruit $50 \%$ de la population folliculaire, quelle que soit la classe de taille, sur le taux d'ovulation, la cyclicité, et les niveaux de progestérone et de FSH au cours des cycles suivant celle-ci, ont été examinés chez des brebis lle de France en saison sexuelle (4 témoins et 16 irradiées).

L'irradiation, effectuée $24 \mathrm{~h}$ après la lutéolyse n'empêche pas l'ovulation chez $87 \%$ des animaux, le taux d'ovulation étant de 1. Parmi les corps jaunes qui en résultent, $78 \%$ sont normaux en niveaux et durée. La FSH s'élève chez les irradiées $20 \mathrm{~h}$ après le traitement et reste supérieure aux témoins jusqu'à l'ovulation. Mais, alors que les niveaux atteints lors du second pic de FSH ne diffèrent pas entre lots, les niveaux ovulatoires élevés persistent chez les brebis irradiées. Au cours des cycles suivants, ni la durée des phases folliculaires, ni le taux d'ovulation, ni les niveaux de progestérone et de $\mathrm{FSH}$ ne diffèrent entre témoins et irradiées.

\section{References}

BAKER T. C., 1966 . The sensitivity of oocytes in post-natal rhesus monkeys to X-irradiation. J. Reprod. Fert., 12, 183-192.

BAST J. D., GREENWALD G. S., 1977. Acute and chronic elevations in serum levels of FSH after unilateral ovariectomy in the cyclic hamster. Endocrinology, 100, 955-966. 
BLANC M. R., POIRIER J. C., 1979. A new homologous radioimmunoassay for ovine follicle-stimulating hormone : development and characterization. Ann. Biol. anim. Bioch. Biophys., 19, 1001-1026.

BLANC M. R., HOCHEREAU de REVIERS M. T., CAHOREAU C., COUROT M., DACHEUX J. L., 1981. Inhibin : effects on gonadotrophin secretion and testis function in the ram and rat. In P. FRANCHIMONT, C. P. CHANNING, Intragonadal regulation of reproduction. Acad. Press, New York.

BUTCHER R. P., 1977. Changes in gonadotrophins and steroids associated with unilateral ovariectomy of the rat. Endocrinology, 101, 830-840.

CAHILL L. P., SAUMANDE J., RAVAULT J. P., BLANC M., THIMONIER J., MARIANA J. C., MAULÉON P., 1981. Hormonal and follicular relationships in ewes of high and low ovulation rate. J. Reprod. Fert., 62, 141-150.

DRIANCOURT M. A., MARIANA J. C., 1982. Short and long-term effects of X-irradiation on ovarian follicular population in the ewe. Reprod. Nutr. Dévelop., 22, 813-823.

DRIANCOURT M. A., PARIS A., ROUX C., MARIANA J. C., PALMER E., 1982. Ovarian follicular populations in pony and saddle-type mares. Reprod. Nutr. Dévelop., 22, 1035-1048.

DUFOUR T. J., CAHILL L. P., MAULÉON P., 1979. Short and long-term effects of hypophysectomy and unilateral ovariectomy on ovarian follicular populations in sheep. J. Reprod. Fert., 57, 301-309.

FINDLAY J. K., CUMMING I. A., 1977. The effect of unilateral ovariectomy on plasma gonadotrophin levels, estrus and ovulation rate in sheep. Biol. Reprod., 17, 178-183.

GOODMAN R. L., PICKOVER S. M., KARSCH F. J., 1981. Ovarian feedback control of follicle stimulating hormone in the ewe : evidence for selective suppression. Endocrinology, 108, $772-777$.

HIRSCHFIELD A., MIDGLEY A. R., 1978a. Morphometric analysis of follicular development in the rat. Biol. Reprod., 19, 597-605.

HIRSCHFIELD A., MIDGLEY A. R., 1978b. The role of FSH in the selection of large ovarian follicles in the rat. Biol. Reprod., 19, 606-611.

HOBSON B. M., BAKER T. G., 1979. Reproductive capacity of rhesus monkeys following bilateral ovarian irradiation. J. Reprod. Fert., 55, 471-480.

HUMPHREYS E. M., ZUCKERMAN S., 1954. Unilateral ovarectomy after X-irradiation of the ovaries. J. Endocr., 10, 155-166.

LACASSAGNE A., 1937. Etude de la radiosensibilité du corps jaune et de la muqueuse utérine au moyen du deciduome artificiel chez la lapine. Radio.-physiol. Radiother., 3, 315-322.

LAND R. B., 1973. Ovulation rate of Finn-Dorset sheep following unilateral ovariectomy or chlorpromazine treatment at different stages of the cestrous cycle. J. Reprod. Fert., 33, 99 105.

MANDL A. M., 1959. A quantitative study of the sensitivity of oocytes to X-irradiation. Proc. roy. Soc. B., 150, 53-71.

MANDL A. M., 1963. The radiosensitivity of oocytes at different staqes of maturation. Proc. roy. Soc. B., 158, 119-141.

PANT H. C., HOPKINSON C. R. N., FITZPATRICK R. J., 1977. Concentration of oestradiol, progesterone, luteinizing hormone and follicle-stimulating hormone in the jugular venous plasma of ewes during the oestrous cycle. J. Endocr., 73, 247-255.

REGAUD C., LACASSAGNE A., 1913. Sur la radiosensibilité aux rayons $X$ des cellules épithéliales des follicules ovariens chez la lapiné. C. R. Soc. Biol. Paris, 74, 1308-1311.

SIEGEL S., 1956. Non-parametric statistics for the behavioural sciences. Mac Graw Hill Book Co., New York.

THIMONIER J., MAULÉON P., 1969. Variations saisonnières du comportement d'oestrus et des activités ovarienne et hypophysaire chez les ovins. Ann. Biol. anim. Bioch. Biophys., 9, 233-250.

YENIKOYE A., MARIANA J. C., LEY J. P., JOLIVET E., TERQUI M., LEMON-RESPLANDY M., 1981. Modèle mathématique de l'évolution de progestérone chez la vache : application et mise en évidence de différences entre races. Reprod. Nutr. Dévelop., 21, 561-575. 